\title{
Demographic Analysis of Financial Literacy Level in Azerbaijan
}

\author{
Nurkhodzha Akbulaev ${ }^{1, *}$, Matanat Mammadova ${ }^{2}$ \\ ${ }^{1}$ UNEC Turkish World Economic Research Center, Department of Economics and Business Administration, Faculty of Economics of \\ Turkish World, Azerbaijan State University of Economics (UNEC), Baku, Azerbaijan \\ ${ }^{2}$ Department of Economics and Business Administration, Faculty of Economics of Turkish World, Azerbaijan State University of \\ Economics (UNEC), Baku, Azerbaijan
}

Received July 13, 2020; Revised February 17, 2021; Accepted May 24, 2021

\section{Cite This Paper in the following Citation Styles}

(a): [1] Nurkhodzha Akbulaev, Matanat Mammadova , "Demographic Analysis of Financial Literacy Level in Azerbaijan," Universal Journal of Accounting and Finance, Vol. 9, No. 3, pp. 316 - 328, 2021. DOI: 10.13189/ujaf.2021.090305.

(b): Nurkhodzha Akbulaev, Matanat Mammadova (2021). Demographic Analysis of Financial Literacy Level in Azerbaijan. Universal Journal of Accounting and Finance, 9(3), 316 - 328. DOI: 10.13189/ujaf.2021.090305.

Copyright@2021 by authors, all rights reserved. Authors agree that this article remains permanently open access under the terms of the Creative Commons Attribution License 4.0 International License

\begin{abstract}
Financial literacy is knowledge that every person needs in everyday life. Studying theory, mastering practical skills, developing financial thinking - all this will allow each of us to become financially successful. Research Objective: The aim of this study is to ascertain the financial literacy level of individuals living in Baku, The Republic of Azerbaijan. 280 people between the ages of 17-60 were involved in the survey, comprised of public and private sector employees, self-employed, retirees and students to attain this objective. Method: SPSS 25.0 for Windows package program was used to evaluate the research data. First of all, frequency was determined in the research. While testing the hypotheses of the research, t-test was applied for independent samples, and Mann Whitney $U$ test was used for comparison of two nonparametric independent groups in the examination of the differences between more than two groups. In addition, the Chi-Square test was utilized to ascertain the degree and direction of the relationship between the relevant variables. Factor analysis has been practised to reduce the number of basic dimensions or group, the variables to facilitate understanding and interpretation of the relationships between multiple variables. In order to decide on the correctness of the answers given to the questions, reliability analysis was performed. Results: In consequence of research, the average level of financial literacy success is determined to be $75 \%$ in Baku. Nevertheless, financial literacy level of the participants differs according to demographic variables such as gender, age, marital status,
\end{abstract}

income, profession, education level. Conclusion: These results can be used to guide policy makers where to place more emphasis in terms of financial education for Azerbaijans.

Keywords Financial Literacy, Financial Education, Financial Behaviors

\section{Introduction}

Financial literacy is a process that enables individual investors and consumers to improve their understanding of the financial products and concepts, to measure their current comprehension, financial risks and opportunities optimally, to make more conscious choices among alternatives, and to do all other effective activities to upgrade the level of their financial well-being Kucukaslan [1]. Financial literacy can be defined as the ability to comprehend financial concepts and issues in order to take the right decisions in the face of changing financial conditions and to manage one's own financial status through financial planning Aksoylu at al. [2]. Financial information literacy helps to manage earnings, especially among those students who study non-commerce subjects Liaqat at al. [3]. In this regard, the improvements in the financial literacy of the individuals through various education programs will probably raise the demand of 
financial products with different risk characteristics and in turn contribute to the development of financial sector Bayar at al. [4]. Financial literacy is very important in the success of any business venture Razak at al. [5].

Financial literacy is to have basic knowledge in finance, the ability to use this financial information and the capability to make the right financial decisions. It is perceived that financial institutions and researchers have emphasized this issue and carried out many studies, different definitions have been made, and concepts of financial literacy, financial knowledge, financial awareness and financial adequacy are used interchangeably [6. p.9].

Changes in the field of finance offer individuals various opportunities, nevertheless individuals are exposed to more risks due to the difficulty in understanding the complexity of increasing financial products and services. It is possible for the individual to follow and understand the financial developments through improving the financial literacy level [7.p.77].

According to Hogarth, Beverly and Hilgert [8]; A person with a good level of financial knowledge who is educated and conversant with banking and insurance, investment, money and asset management is a conscious consumer.

The diversity in financial tools, techniques and practices as a result of the change in financial architecture causes financial literacy to increase in importance. Individuals' demand for financial security also contributes to the development of financial literacy. For this reason, it is significant to eliminate the existing information gaps regarding financial services such as credit card use, consumer loans, insurance, private pension plans, housing loans, refinancing, monitoring and recording financial data. Increasing the level of financial literacy helps individuals make financial decisions by enlightening them about the way financial products and services work and which ones are more compatible with their interests. Enhancing financial literacy allows to have more information about the financial system and to better manage financial risks.

It is evident that educational programs meeting requirements of the field should be developed in order to reinforce the effectiveness of the concept of financial literacy, which increases in prominance,. The prerequisite for developing training programs is to determine the size and content of training needs. These demands may appear distinctly in different segments of the society. Therefore, determining the boundaries of the target audience and revealing the needs of this community are considered as a point that should be emphasized.

The purpose of this study is to determine the financial literacy level of individuals who live in Baku, The Republic of Azerbaijan. The differentiation in the level of financial literacy in question corresponding to demographic variables will be also specified. For these purposes, a survey has been applied to 280 people who are public and private sector employees, self-employed, retirees and students.
Numerous studies have been conducted on financial literacy in the national and international literature. The distinctive feature of this study is that aforementioned studies have included students or certain professions in a single province of the countries, however there has not been a comprehensive study of this type carried out for Azerbaijan. This research differs from other studies in terms of its application to all professional groups as well.

\section{Literature Review}

There have been several studies carried on financial literacy in the national and international literature. An important part of these studies has been applied to students or certain professions. Some of these studies are summarized below.

Kilich, Ata and Seyrek [9] investigated the financial literacy levels of university students. In the study, the overall level of financial literacy of students was stated as $48 \%$. In addition, the authors found that male students had higher financial literacy than female students. Also, in studies investigating the correlation between financial literacy and gender Worthington [10] Dvorak and Hanley [11], it was revealed that men have higher financial literacy than women.

Barish [12] examined the financial literacy level of Gaziosmanpaşa University FEAS students. As a result of the research, it was ascertained that students' advanced financial literacy was low. In addition, female students were found to have higher financial literacy than male students. Similarly, Ozdemir et al. [13] examined the financial literacy level of Anadolu University FEAS students. They determined that the financial literacy levels of nearly half of their students were high due to the study.

Bicher [14] conducted an investigation about the financial literacy levels of students studying at Cumhuriyet University Faculty of Health Sciences. As a consequence of the study, it has been found out that the level of financial literacy diversifies depending on the department, class and gender of the students.

Shamiloglu, Kahraman and Bagci [15] identified the general financial literacy level of students studying at Erciyes University. As an outcome of the study, it was uncovered that the literacy level of business students was higher than other department students; meanwhile, male students had better financial literacy than female students. Similarly, Authors such as Shantash and Demirgil [16]; Ergun, Shahin and Ergin [17]; Sarigul [18]; Bayram [19]; Danes and Hira [20]; Volpe, Chen and Pavlicko [21]; Chen and Volpe [22]; Kieschnick [23]; Jorgensen [24]; Mandell and Klein [25]; Robb and Sharpe [26] and Cameron et al. [27] figured out the financial literacy level of their students.

Yardimoglu and Yoruk [28] investigated the financial literacy levels of civil servants, tradesmen and other professional groups working in Kahramanmarash. In 
consequence of the study, they found that as employees' financial awareness increased, their financial literacy also increased.

Yıldırım at al. [29] results statistical analyses displayed that from demographic variables only education and monthly income was important determinant, both of basic and advantage financial literacy.

Baker at al. [30] results reveal the presence of different behavioral biases including overconfidence and self-attribution, the disposition effect, anchoring bias, representativeness, mental accounting, emotional biases and herding among Indian investors.

Setyowati at al. [31] measured the level of Islamic financial literacy (IFL) in an individual society and test the impact of IFL on personal financial planning.

Shusha[32] in an attempt to clarify controversial issues by examining the regulatory role of financial literacy in the relationship between demographic characteristics and financial risk tolerance.

Janor at al. [33] the results of a study in Malaysia show that overall FL levels are low in both countries and the government should take the necessary steps to raise awareness of financial issues.

Dewanty and Isbanah [34] this study examined the influence of demographic factors and the factor of financial socialization on financial literacy.

Aksoylu at al. [2] the study was conducted to determine the financial literacy levels of people living in Kayseri province, and to examine possible relationships between financial literacy levels and the demographic characteristics of people.

Garg and Singh [35] the study shows that the financial literacy rate of young people in much of the world is low, which is a cause for concern. It was also found that socioeconomic and demographic factors such as age, gender, income, marital status and educational level affect the level of financial literacy of young people and there is a relationship between financial knowledge, financial attitude and financial behavior.

Kimiyaghalam and Yap [36] investigated the level of financial literacy of Malaysians living in the Klang Valley. The results of the analysis showed that, in general, $51.54 \%$ of Malaysians have basic financial knowledge, and if financial literacy improves, this figure drops to $37 \%$. There is no clear difference between the level of financial literacy.

Nanziri and Leibbrandt [37] researched the financial literacy of the people of South Africa. The index found significant differences in financial literacy by age, education, province and race. Overall, demographics account for up to $10 \%$ of the differences in financial literacy among people in South Africa.

Widityani at al. [38] investigated the factors that increase Islamic financial literacy among college students in Indonesia. The study found that the type of institution, experience of studying in Islamic finance courses, master's degree education, own income, and income of more than five million have a lot to do with the Islamic financial literacy of college students.

Liaqat at al. [3] investigated attempted to examine differences in such literacy through their demographic and socioeconomic characteristics, level of financial knowledge among university students.

Bayar at al. [4] this paper investigated the influence of financial literacy and demographic characteristics on financial risk tolerance of individuals in a sample of Usak University staff using polynomial logistic regression analysis and obtaining data using a questionnaire method. Empirical analyzes have shown that financial literacy and demographics of age, gender, education, and income levels are important determinants of financial risk resilience.

Asbi at al. [39] investigated the contribution of demographic factors, behavioral characteristics and financial literacy to recovery from financial losses caused by the Black Saturday wildfire. The results showed that the factors of demographic, behavioral and financial literacy can help accelerate the recovery process.

Oztop and Kuyu [40] in this work, the researchers attempted to identify the factors that influence people's tolerance for financial risk. The results of the study showed that there is a statistically positive and significant relationship between positive emotional state, age, and financial risk tolerance.

Marime at al. [41] the goal of the researchers was to incorporate demographic factors such as gender, age, marital status and education into the financial literacy of microentrepreneurs. The study found that entrepreneurial businesses throughout Malaysia fail because of unsatisfactorily low financial literacy.

Lusardi [42,43] carried out research on the levels of financial literacy of individuals and as a consequence of the study he revealed that African Americans and Latin Americans obtained low financial knowledge.

Singh and Kumar [44] the aim of this study was to provide an overview of the financial literacy of women in a developing country using the example of India. As a result, it is revealed that, where poverty and unemployment are the main problems, it is very important to teach women about financial literacy so that they fuel the engine of growth, giving women the opportunity to contribute to economic growth.

Schagen and Lines [45] stated that this concept is based on three main skills: financial planning, problem solving, and decision making. The authors argued that a financial literate person will be able to understand the main concepts of money management, have knowledge about the way financial institutions, systems and services work, and will have the attitude to create an environment of efficiency and soundness in the management of financial issues [46].

Ahmadov at al. [47] They emphasized that individuals' expertise to understand income, investment experience and personal budget management, financial literacy as an 
identifiable concept, complex financial decision-making processes and decisions on individuals, but against the background of information on the impact of the country's economic system, is as vital as the world economy.

\section{The Importance of Research}

The fact that finance is almost in every stage of individuals' life makes it a necessity for them to manage their own financial situation. As a matter of fact, it is important for individuals to have knowledge about basic financial concepts, tools and problems for the existence of an efficient working market. Financial markets and changes in the demographic structure of the society increase the significance of financial literacy.

On the one hand, the increase in living standards and quality, on the other hand, essential economic changes indicate the significance of financial decisions and the need to be well-informed. It is crucial to overcome the shortcomings that exist in financial management issues such as basic credit card use, personal loans, insurance, monitoring and recording financial data. Theoretically, understanding how financial products and services work and which ones are oriented to personal interests will sustain individuals in how and when to make financial decisions.

The fact that an analogous study designed to ascertain the level of financial literacy has not been done at an academic level in Baku signifies the momentousness of this study. On the other hand, the findings from such a study will reveal the level of comprehension of individuals about financial literacy, their success in managing the financial situation, whether they will require a program on education. The level of financial literacy will be increased, it will be determined which financial education programs will be structured concerning the areas, concepts and behaviors, and which tools will be used to publicize it in the society. This study that will be deemed to be a pilot study on financial literacy will pave the way for further researches.

The matter that acknowledged persons get into the financial markets and benefit from the opportunities will ensure that the financial system functions well, and those individuals can see the financial risks and make correct and timely decisions.

\section{Purpose of the Research}

The main purpose of the research is to determine the financial literacy status of individuals and their behavior towards managing the financial situation. Based on this purpose, how much information individuals have on financial literacy, what resources they use to make financial decisions, how sufficient they consider themselves about financial literacy, how much they know about some financial concepts, credit card usage status, following financial news frequency are identified.
Moreover, it was aimed to investigate individuals' habits of keeping financial records, which of the basic financial instruments they use, by the means of which sources they follow financial developments, the important conditions in the use and application of credit cards, saving status, whether they make a monthly budget and act in compliance.

\section{Scope of the Research}

The population participated in survey consists of people from all strata who are aged 17 and over and reside in Baku. A survey was carried out by reaching 280 people through random sampling. With this study, it is intended to specify the financial literacy level of people.

\section{Analysis Methods Used in Research}

SPSS 25.0 for Windows package program was used to evaluate the research data. First of all, frequency (frequency or percentage distribution) was determined in the research. While testing the hypotheses of the research, t-test (Independent Samples T-test) was applied for independent samples, and Mann Whitney U test was used for comparison of two nonparametric independent groups in the examination of the differences between more than two groups. In addition, the Chi-Square (crosstabs) test was utilized to ascertain the degree and direction of the relationship between the relevant variables. Factor analysis has been practised to reduce the number of basic dimensions or group the variables to facilitate understanding and interpretation of the relationships between multiple variables. In order to decide on the correctness of the answers given to the questions, reliability analysis was performed.

\section{Hypotheses}

H1: Responses for calculating the time value of money vary in terms of gender groups.

$\mathrm{H} 2$ : Responses for calculating mortgage interest differ in regard with gender groups.

H3: There is no significant relationship between the answers of the questions regarding the deposit and gender groups.

H4: There is no noteworthy correlation between the answers of the questions in regard to inflation and gender groups.

H5: The responses concerning retirement do not show an alteration in terms of gender groups.

H6: Reponses as to credit rates and inflation do not change in the context of gender groups.

H7: Answers of the questions about calculating the time value of money are not subject to variation in terms of age groups. 
H8: There is a significant relationship between age ratios and answers related to credit rates and inflation.

H9: Answers about figuring out the time value of money vary in terms of income level groups.

H10: Answers regarding calculation of mortgage interest differ as to income level groups.

H11: There is a notable link between retirement responses and income level groups.

H12: There is a marked correlation between credit rates and inflation related answers and income level groups.

\section{Research Findings}

\section{Descriptive Statistics of Financial Literacy Level Based on Demographic Characteristics}

Six test questions were asked to measure the financial literacy level of the participants. Descriptive analysis regarding the answers provided for the questions and demographic groups in reference to them are presented in the tables below.

Initially, responses to financial literacy tests in terms of gender were evaluated.

Table 1. Frequencies as to Variables

\begin{tabular}{|c|c|c|c|c|}
\hline \multicolumn{5}{|c|}{ Crosstab } \\
\hline \multicolumn{5}{|l|}{ Count } \\
\hline & & \multicolumn{2}{|c|}{ Test 1 . The present value of money } & \multirow{2}{*}{ Total } \\
\hline & & Incorrect & Correct & \\
\hline \multirow{2}{*}{ Gender } & Men & 59 & 70 & 129 \\
\hline & Women & 83 & 53 & 136 \\
\hline \multicolumn{2}{|c|}{ Total } & 142 & 123 & 265 \\
\hline
\end{tabular}

The number of respondents answering the test questionnaire related to the "Present value of money" totalled 265. As illustrated in the table above, 142 people answered incorrectly and 123 responded correctly. Of the respondents giving right answers, 70 were men and 53 were women.

Table 2. Frequencies Regarding Variables

\begin{tabular}{|c|c|c|c|c|}
\hline \multicolumn{5}{|c|}{ Crosstab } \\
\hline \multicolumn{5}{|l|}{ Count } \\
\hline & & \multicolumn{2}{|c|}{ Test 2. Calculation of mortgage interest } & \multirow{2}{*}{ Total } \\
\hline & & Incorrect & Correct & \\
\hline \multirow{2}{*}{ Gender } & Men & 28 & 105 & 133 \\
\hline & Women & 34 & 102 & 136 \\
\hline \multicolumn{2}{|c|}{ Total } & 62 & 207 & 269 \\
\hline
\end{tabular}

A total of 269 people answered to the test related to "Calculating mortgage interest rate", which is one of the financial literacy tests. 133 of them were men and 136 were women. 62 people answered the test incorrectly and 207 responded correctly. Of the correct answers, 105 were male and 102 were female correspondents.

Table 3. Frequencies Related to Variables

\begin{tabular}{|c|c|c|c|c|}
\hline \multicolumn{5}{|l|}{ Crosstab } \\
\hline \multicolumn{5}{|l|}{ Count } \\
\hline & & \multicolumn{2}{|c|}{ Test 3. Time Deposit } & \multirow{2}{*}{ Total } \\
\hline & & Incorrect & Correct & \\
\hline \multirow{2}{*}{ Gender } & Men & 11 & 122 & 133 \\
\hline & Women & 18 & 118 & 136 \\
\hline \multicolumn{2}{|c|}{ Total } & 29 & 240 & 269 \\
\hline
\end{tabular}

The third test was addressed to the participants related to the time deposit. As is shown in Table 3, overall, 269 people were involved in this test. 133 of them were male and 136 were female participants. A total of 240 people answered this question in a correct way, while 29 gave a wrong answer. 122 of them were men and 118 were women.

Table 4. Frequencies Regarding Variables

\begin{tabular}{|c|c|c|c|c|}
\hline \multicolumn{5}{|l|}{ Crosstab } \\
\hline \multicolumn{5}{|l|}{ Count } \\
\hline & & \multicolumn{2}{|c|}{ Test 4. Inflation } & \multirow{2}{*}{ Total } \\
\hline & & Incorrect & Correct & \\
\hline \multirow{2}{*}{ Gender } & Men & 14 & 121 & 135 \\
\hline & Women & 18 & 116 & 134 \\
\hline \multicolumn{2}{|c|}{ Total } & 32 & 237 & 269 \\
\hline
\end{tabular}

Participants were asked to solve the inflation-related test in question 4. 269 people; 135 men and 134 women, answered the question. 32 of them answered the question inaccurately and 237 answered the question accurately. 121 of the correspondents giving the accurate answer were men while 116 were women.

Table 5. Frequency Values Related to Variables

\begin{tabular}{|c|c|c|c|c|}
\hline \multicolumn{5}{|l|}{ Crosstab } \\
\hline \multicolumn{5}{|l|}{ Count } \\
\hline & & \multicolumn{2}{|c|}{ Test 5. Retirement } & \multirow{2}{*}{ Total } \\
\hline & & Incorrect & Correct & \\
\hline \multirow{2}{*}{ Gender } & Men & 25 & 109 & 134 \\
\hline & Women & 30 & 107 & 137 \\
\hline \multicolumn{2}{|c|}{ Total } & 55 & 216 & 271 \\
\hline
\end{tabular}

The 5th test to measure the level of financial literacy is about retirement. The complete sum of the participants was 271 people; with 134 men and 137 women, answering this test. 55 of the answers were wrong and 216 were correct. Of those who replied accurately, 109 were men and 107 were women. 
Table 6. Frequencies in Regard to Variables

\begin{tabular}{|c|c|c|c|c|}
\hline \multicolumn{5}{|c|}{ Crosstab } \\
\hline \multicolumn{5}{|l|}{ Count } \\
\hline & & \multicolumn{2}{|c|}{ Test 6. Credit rates and inflation } & \multirow{2}{*}{ Total } \\
\hline & & Incorrect & Correct & \\
\hline \multirow{2}{*}{ Gender } & Men & 58 & 72 & 130 \\
\hline & Women & 75 & 60 & 135 \\
\hline \multicolumn{2}{|c|}{ Total } & 133 & 132 & 265 \\
\hline
\end{tabular}

Table 6 reports the number of correspondents consisting of 130 male and 135 female participants. 133 of the answers were inaccurate and 132 were accurate. 72 of participants giving right answers were men and 60 were women.

When we consider the financial literacy level in terms of gender, we can infer from the Crosstab analysis that, although the number of male participants constitutes lower proportion of all participants, the number of men who answered correctly to each question is superior in number. Nevertheless, we can draw the strong conclusions on whether the answers vary in respect to gender only based on hypothesis tests.

Similarly, descriptive analyzes were conducted to measure the level of financial literacy according to age and income level, and the results are represented in the tables below.

Table 7. Frequency Analysis by Age

\begin{tabular}{|c|c|c|c|c|c|}
\hline \multicolumn{6}{|c|}{ Age } \\
\hline & & Frequency & Percent & Valid Percent & $\begin{array}{c}\text { Cumulative } \\
\text { Percent }\end{array}$ \\
\hline \multirow{8}{*}{ Valid } & $17-20$ & 23 & 8,2 & 8,8 & 8,8 \\
\hline & $21-24$ & 32 & 11,4 & 12,3 & 21,1 \\
\hline & $25-28$ & 71 & 25,3 & 27,2 & 48,3 \\
\hline & $29-32$ & 70 & 24,9 & 26,8 & 75,1 \\
\hline & 33-36 & 21 & 7,5 & 8,0 & 83,1 \\
\hline & $37-40$ & 12 & 4,3 & 4,6 & 87,7 \\
\hline & 41 and over & 32 & 11,4 & 12,3 & 100,0 \\
\hline & Total & 261 & 92,9 & 100,0 & \\
\hline Missing & System & 20 & 7,1 & & \\
\hline & Total & 281 & 100,0 & & \\
\hline
\end{tabular}

Totally 261 people answered the question about age, 23 of them were between 17-20 years old, 32 were between 21-24 years old, 71 were between 25 -28 years old, 70 were between 29-32 years old, 21 were 33-36 and 32 of them were 41 and over.

As is apparent from the table 8, the highest number of wrong answers in the test question about the present value of money was given by the people in the age group of 41 and over.

As can be seen from table 9, the minimum number of errors in this test question was made by the people in the age group of 41 years and older compared to the number of other respondents in their group. 199 of 257 people in total answered this question accurately.

Table 8. Frequency Analysis by Variables

\begin{tabular}{|c|c|c|c|c|}
\hline \multicolumn{5}{|c|}{ Crosstab } \\
\hline \multicolumn{5}{|l|}{ Count } \\
\hline & & \multicolumn{2}{|c|}{$\begin{array}{c}\text { Test } 1 \text {. The present value of } \\
\text { money }\end{array}$} & \multirow{2}{*}{ Total } \\
\hline & & Incorrect & Correct & \\
\hline \multirow{7}{*}{ Age } & $17-20$ & 11 & 11 & 22 \\
\hline & $21-24$ & 13 & 17 & 30 \\
\hline & $25-28$ & 34 & 37 & 71 \\
\hline & $29-32$ & 33 & 34 & 67 \\
\hline & $33-36$ & 11 & 9 & 20 \\
\hline & $37-40$ & 5 & 6 & 11 \\
\hline & 41 and over & 25 & 6 & 31 \\
\hline \multicolumn{2}{|c|}{ Total } & 132 & 120 & 252 \\
\hline
\end{tabular}

Table 9. Frequency Analysis by Variables

\begin{tabular}{|c|c|c|c|c|}
\hline \multicolumn{5}{|c|}{ Crosstab } \\
\hline \multicolumn{5}{|c|}{ Count } \\
\hline & & \multicolumn{2}{|c|}{$\begin{array}{c}\text { Test 2. Calculation of mortgage } \\
\text { interest }\end{array}$} & \multirow[t]{2}{*}{ Total } \\
\hline & & Incorrect & Correct & \\
\hline \multirow{7}{*}{ Age } & $17-20$ & 10 & 12 & 22 \\
\hline & $21-24$ & 7 & 24 & 31 \\
\hline & $25-28$ & 18 & 53 & 71 \\
\hline & $29-32$ & 9 & 61 & 70 \\
\hline & $33-36$ & 5 & 15 & 20 \\
\hline & $37-40$ & 6 & 6 & 12 \\
\hline & 41 and over & 3 & 28 & 31 \\
\hline \multicolumn{2}{|r|}{ Total } & 58 & 199 & 257 \\
\hline
\end{tabular}

Table 10. Frequency Analysis by Variables

\begin{tabular}{|c|c|c|c|c|}
\hline \multicolumn{5}{|c|}{ Crosstab } \\
\hline \multicolumn{5}{|l|}{ Count } \\
\hline & & \multicolumn{2}{|c|}{ Test 3. Deposit } & \multirow{2}{*}{ Total } \\
\hline & & Incorrect & Correct & \\
\hline \multirow{7}{*}{ Age } & $17-20$ & 3 & 19 & 22 \\
\hline & $21-24$ & 2 & 30 & 32 \\
\hline & $25-28$ & 4 & 66 & 70 \\
\hline & 29-32 & 7 & 63 & 70 \\
\hline & $33-36$ & 4 & 16 & 20 \\
\hline & $37-40$ & 2 & 9 & 11 \\
\hline & 41 and over & 6 & 25 & 31 \\
\hline \multicolumn{2}{|c|}{ Total } & 28 & 228 & 256 \\
\hline
\end{tabular}


As is evident from table 10, 70 people answered the question about the deposit both in the 25-28 age group and in the 29-32 age group. People who are between the ages of 25-28 have made the least mistake between the two.

Table 11. Frequency Analysis by Variables

\begin{tabular}{|c|c|c|c|c|}
\hline \multicolumn{5}{|c|}{ Crosstab } \\
\hline \multicolumn{5}{|l|}{ Count } \\
\hline & & \multicolumn{2}{|c|}{ Test 4. Inflation } & \multirow{2}{*}{ Total } \\
\hline & & Incorrect & Correct & \\
\hline \multirow{7}{*}{ Age } & $17-20$ & 1 & 21 & 22 \\
\hline & $21-24$ & 3 & 28 & 31 \\
\hline & $25-28$ & 10 & 57 & 67 \\
\hline & $29-32$ & 5 & 63 & 68 \\
\hline & $33-36$ & 5 & 16 & 21 \\
\hline & $37-40$ & 1 & 10 & 11 \\
\hline & 41 and over & 5 & 27 & 32 \\
\hline \multicolumn{2}{|c|}{ Total } & 30 & 222 & 252 \\
\hline
\end{tabular}

The outstanding situation in this test question is that those who has made the least mistakes are those in the 17-20 age group. Only 1 out of 22 people answered this question incorrectly.
Table 12. Frequency Analysis by Variables

\begin{tabular}{|c|c|c|c|c|}
\hline \multicolumn{5}{|c|}{ Crosstab } \\
\hline \multicolumn{5}{|l|}{ Count } \\
\hline & & \multicolumn{2}{|c|}{ Test 5. Retirement } & \multirow{2}{*}{ Total } \\
\hline & & Incorrect & Correct & \\
\hline \multirow{7}{*}{ Age } & $17-20$ & 10 & 13 & 23 \\
\hline & $21-24$ & 4 & 28 & 32 \\
\hline & $25-28$ & 10 & 61 & 71 \\
\hline & 29-32 & 10 & 59 & 69 \\
\hline & $33-36$ & 3 & 17 & 20 \\
\hline & $37-40$ & 5 & 7 & 12 \\
\hline & 41 and over & 9 & 22 & 31 \\
\hline \multicolumn{2}{|c|}{ Total } & 51 & 207 & 258 \\
\hline
\end{tabular}

Of the 258 people, 207 of them answered accurately and 51 of them answered inaccurately. According to the number of respondents, people in the 37-40 age group made more mistakes.

Looking at Table 13, we can notice that the number of people who replied incorrectly to this question was more than those who answered correctly. People who are between the ages of 21-24 have made the most mistakes in their group.

In the table below, the frequency analysis related to income level groups is presented.

Table 13. Frequency Analysis by Variables

\begin{tabular}{|c|c|c|c|c|}
\hline \multicolumn{5}{|l|}{ Crosstab } \\
\hline \multicolumn{5}{|l|}{ Count } \\
\hline & & \multicolumn{2}{|c|}{ Test 6. Relationship between credit rates and inflation } & \multirow{2}{*}{ Total } \\
\hline & & Incorrect & Correct & \\
\hline \multirow{7}{*}{ Age } & $17-20$ & 16 & 6 & 22 \\
\hline & $21-24$ & 20 & 10 & 30 \\
\hline & $25-28$ & 35 & 34 & 69 \\
\hline & 29-32 & 33 & 36 & 69 \\
\hline & $33-36$ & 6 & 14 & 20 \\
\hline & $37-40$ & 3 & 8 & 11 \\
\hline & 41 and over & 14 & 17 & 31 \\
\hline \multicolumn{2}{|c|}{ Total } & 127 & 125 & 252 \\
\hline
\end{tabular}

Table 14. Frequency Analysis Regarding Income Level

\begin{tabular}{|c|c|c|c|c|c|}
\hline \multicolumn{6}{|c|}{ Your Monthly Income } \\
\hline & & Frequency & Percent & Valid Percent & Cumulative Percent \\
\hline \multirow{6}{*}{ Valid } & 250 AZN and below & 38 & 13,5 & 14,0 & 14,0 \\
\hline & 250-500 AZN & 48 & 17,1 & 17,7 & 31,7 \\
\hline & 501-750 AZN & 44 & 15,7 & 16,2 & 48,0 \\
\hline & 751-1500 AZN & 96 & 34,2 & 35,4 & 83,4 \\
\hline & 1501 AZN and over & 45 & 16,0 & 16,6 & 100,0 \\
\hline & Total & 271 & 96,4 & 100,0 & \\
\hline Missing & System & 10 & 3,6 & & \\
\hline \multicolumn{2}{|r|}{ Total } & 281 & 100,0 & & \\
\hline
\end{tabular}


A sum of 271 people answered this question. When we look at the table, we can state that 96 people chose the 751-1500 Azn option and this number constitutes $34.2 \%$ of the total participants.

\section{Testing Hypotheses}

$\mathrm{H}_{1}$ : Responses for calculating the time value of money vary in terms of gender groups.

Table 15. Chi-Square Test Results

\begin{tabular}{|c|c|c|c|c|c|}
\hline \multicolumn{7}{|c|}{ Chi-Square Tests } \\
\hline & Value & Df & $\begin{array}{c}\text { Asymptotic Significance } \\
\text { (2-sided) }\end{array}$ & Exact Sig. (2-sided) & Exact Sig. (1-sided) \\
\hline Pearson Chi-Square & $6,225^{\mathrm{a}}$ & 1 &, 013 & & \\
\hline Continuity Correction ${ }^{\mathrm{b}}$ & 5,626 & 1 &, 018 & & \\
\hline Likelihood Ratio & 6,248 & 1 &, 012 &, 014 & \\
\hline Fisher's Exact Test & & & & & \\
\hline Linear-by-Linear Association & 6,202 & 1 & 013 & \\
\hline N of Valid Cases & 265 & & & & \\
\hline a. 0 cells (0,0\%) have expected count less than 5. The minimum expected count is 59,88. & \\
\hline b. Computed only for a 2x2 table
\end{tabular}

Chi Square test has been used to test $\mathrm{H}_{1}$. And according to the results of the test, since the Assymp. Sig value (0.013) is less than 0.05 , we can say that the answers given regarding the time value of money change in terms of gender groups. For this reason, $\mathrm{H}_{1}$ has been accepted.

$\mathrm{H}_{2}$ : Responses for calculating mortgage interest differ in regard with gender groups.

Table 16. Chi Square Test Results

\begin{tabular}{|c|c|c|c|c|c|}
\hline \multicolumn{7}{|c|}{ Chi-Square Tests } \\
\hline & Value & Df & Asymptotic Significance (2-sided) & Exact Sig. (2-sided) & Exact Sig. (1-sided) \\
\hline Pearson Chi-Square &, $591^{\mathrm{a}}$ & 1 &, 442 & & \\
\hline Continuity Correction ${ }^{\mathrm{b}}$ &, 389 & 1 &, 533 & & \\
\hline Likelihood Ratio &, 592 & 1 &, 442 & &, 267 \\
\hline Fisher's Exact Test & & & & & \\
\hline Linear-by-Linear Association &, 589 & 1 & 443 & & \\
\hline N of Valid Cases & 269 & & & & \\
\hline a. 0 cells (0,0\%) have expected count less than 5. The minimum expected count is 30,65. & \\
\hline \\
b. Computed only for a 2x2 table
\end{tabular}

Chi Square test has been applied to verify the $\mathrm{H}_{2}$ hypothesis. As determined by the results of the test, Assymp. Sig value is 0.442 . Since this value is higher than 0.05 , we can say that the answers given about the mortgage do not show an alteration in regard to gender groups. For this reason, $\mathrm{H}_{2}$ has been refuted.

$\mathrm{H}_{3}$ : There is no significant relationship between the answers of the questions regarding the deposit and gender groups.

Table 17. Results Based on Chi-Square Test

\begin{tabular}{|c|c|c|c|c|c|}
\hline \multicolumn{7}{|c|}{ Chi-Square Tests } \\
\hline & Value & Df & $\begin{array}{c}\text { Asymptotic Significance } \\
\text { (2-sided) }\end{array}$ & Exact Sig. (2-sided) & Exact Sig. (1-sided) \\
\hline Pearson Chi-Square & $1,723^{\mathrm{a}}$ & 1 &, 189 & & \\
\hline Continuity Correction ${ }^{\mathrm{b}}$ & 1,246 & 1 &, 264 & & \\
\hline Likelihood Ratio & 1,740 & 1 &, 187 &, 239 &, 132 \\
\hline Fisher's Exact Test & & & & & \\
\hline Linear-by-Linear Association & 1,717 & 1 & & & \\
\hline N of Valid Cases & 269 & & & & \\
\hline a. 0 cells $(0,0 \%$ ) have expected count less than 5. The minimum expected count is 14,34. & \\
\hline b. Computed only for a 2x2 table \\
\hline
\end{tabular}


The results of the KI Square test applied to examine whether there is a significant relationship between the answers given to the deposit and the gender groups are given in Table 17. When we look at the table, we can observe that the Assymp. Sig value is 0.189 . Since this value is $\mathrm{p}>0.05$, there is no significant relationship between the two variables. $\mathrm{H}_{3}$ has been accepted.

$\mathrm{H}_{4}$ : There is no noteworthy correlation between the answers of the questions in regard to inflation and gender groups.

Table 18. Chi Square Test Results

\begin{tabular}{|c|c|c|c|c|c|}
\hline & Value & Df & $\begin{array}{c}\text { Asymptotic Significance } \\
\text { (2-sided) }\end{array}$ & Exact Sig. (2-sided) & Exact Sig. (1-sided) \\
\hline Pearson Chi-Square &, $602^{\mathrm{a}}$ & 1 &, 438 & & \\
\hline Continuity Correction ${ }^{\mathrm{b}}$ &, 345 & 1 &, 557 & & \\
\hline Likelihood Ratio &, 603 & 1 &, 437 & &, 279 \\
\hline Fisher's Exact Test & & & & & \\
\hline Linear-by-Linear Association &, 600 & 1 & 439 & & \\
\hline N of Valid Cases & 269 & & & & \\
\hline a. 0 cells (0,0\%) have expected count less than 5. The minimum expected count is 15,94. & \\
\hline \\
b. Computed only for a 2x2 table
\end{tabular}

The results of the KI Square test undergone to identify whether there is a significant relationship between the answers asked about inflation and gender groups are presented in Table 18. As indicated in the table, the Assymp. Sig value is 0.438 . Since this value is $\mathrm{p}>0.05$, there is no significant relationship between the two variables. $\mathrm{H}_{4}$ has been accepted.

$\mathrm{H}_{5}$ : The responses concerning retirement do not show an alteration in terms of gender groups.

Chi Square test has been carried out to test the hypothesis, and the results are given in Table 19. When we look at the table, we can observe that the Assymp. Sig value is 0.507 . Since this value is $p>0.05$, retirement responses are not subject to variation in regard to gender groups. Therefore, $\mathrm{H}_{5}$ has been accepted.

Table 19. Chi-square Test Results

\begin{tabular}{|c|c|c|c|c|c|}
\hline & Value & Df & $\begin{array}{c}\text { Asymptotic Significance } \\
\text { (2-sided) }\end{array}$ & Exact Sig. (2-sided) & Exact Sig. (1-sided) \\
\hline Pearson Chi-Square &, $440^{\mathrm{a}}$ & 1 &, 507 & & \\
\hline Continuity Correction &, 262 & 1 &, 609 & & \\
\hline Likelihood Ratio &, 440 & 1 &, 507 &, 548 &, 304 \\
\hline Fisher's Exact Test & & & & & \\
\hline Linear-by-Linear Association &, 438 & 1 & & & \\
\hline N of Valid Cases & 271 & & & & \\
\hline a. 0 cells (0,0\%) have expected count less than 5. The minimum expected count is 27,20. & \\
\hline b. Computed only for a 2x2 table
\end{tabular}

$\mathrm{H}_{6}$ : Reponses as to credit rates and inflation do not change in the context of gender groups.

Chi square test has been conducted to investigate this hypothesis. The results are presented in Table 20. According to the results of the chi-square test, Asymp. Sig value is 0.075. Although it is close to 0.05 , it does not necessarily ensure that the answers related to credit rates and inflation show a change in terms of gender groups $(\mathrm{p}>0.05)$. For this reason, $\mathrm{H}_{6}$ has been accepted. 
Table 20. Chi Square Test Results

\begin{tabular}{|c|c|c|c|c|c|}
\hline & Value & Df & $\begin{array}{c}\text { Asymptotic Significance } \\
\text { (2-sided) }\end{array}$ & Exact Sig. (2-sided) & Exact Sig. (1-sided) \\
\hline Pearson Chi-Square & $3,171^{\mathrm{a}}$ & 1 &, 075 & & \\
\hline Continuity Correction ${ }^{\mathrm{b}}$ & 2,748 & 1 &, 097 & & \\
\hline Likelihood Ratio & 3,177 & 1 &, 075 &, 049 \\
\hline Fisher's Exact Test & & & & & \\
\hline Linear-by-Linear Association & 3,159 & 1 & 076 & & \\
\hline N of Valid Cases & 265 & & & & \\
\hline a. 0 cells (0,0\%) have expected count less than 5. The minimum expected count is 64,75. & \\
\hline b. Computed only for a 2x2 table
\end{tabular}

$\mathrm{H}_{7}$ : Answers of the questions about calculating the time value of money are not subject to variation in terms of age groups

Chi Square test has been carried out to test the hypothesis, and the results are given in Table 21. It can be inferred from the table that the Assymp. Sig value is 0.060 . Since this value is $p>0.05$, the answers regarding the present value of money do not differ in terms of age groups. Thus, $\mathrm{H}_{7}$ has been rejected.

Table 21. Chi Square Test Results

\begin{tabular}{|c|c|c|c|}
\hline \multicolumn{4}{|c|}{ Chi-Square Tests } \\
\hline & Value & Df & $\begin{array}{c}\text { Asymptotic } \\
\text { Significance } \\
\text { (2-sided) }\end{array}$ \\
\hline Pearson Chi-Square & $12,067^{\mathrm{a}}$ & 6 &, 060 \\
\hline Likelihood Ratio & 12,909 & 6 &, 045 \\
\hline $\begin{array}{c}\text { Linear-by-Linear } \\
\text { Association }\end{array}$ & 7,012 & 1 &, 008 \\
\hline N of Valid Cases & 252 & & \\
\hline
\end{tabular}

a. 0 cells $(0,0 \%)$ have expected count less than 5 . The minimum expected count is 5,24 .

$\mathrm{H}_{8}$ : There is an appreciable relationship between age ratios and answers related to credit rates and inflation.

Table 22. Chi Square Test Results

\begin{tabular}{|c|c|c|c|}
\hline \multicolumn{4}{|c|}{ Chi-Square Tests } \\
\hline & Value & Df & $\begin{array}{c}\text { Asymptotic } \\
\text { Significance } \\
\text { (2-sided) }\end{array}$ \\
\hline Pearson Chi-Square & $13,772^{\mathrm{a}}$ & 6 & ,032 \\
\hline Likelihood Ratio & 14,184 & 6 & ,028 \\
\hline $\begin{array}{l}\text { Linear-by-Linear } \\
\text { Association }\end{array}$ & 8,364 & 1 & ,004 \\
\hline $\mathrm{N}$ of Valid Cases & 252 & & \\
\hline
\end{tabular}

When the results of Chi Square Test is examined, we find out that Asymp. Sig value is 0.032 . Considering that this value is less than 0.05 , there is a notable correlation between credit rates and inflation-related responses and age groups. $\mathrm{H}_{8}$ has been accepted.
$\mathrm{H}_{9}$ : Answers about figuring out the time value of money vary in terms of income level groups.

Table 23. Chi-Square Test Results

\begin{tabular}{|c|c|c|c|}
\hline \multicolumn{4}{|c|}{ Chi-Square Tests } \\
\hline & Value & Df & $\begin{array}{c}\text { Asymptotic } \\
\text { Significance (2-sided) }\end{array}$ \\
\hline Pearson Chi-Square & 2,713a & 4 & ,607 \\
\hline Likelihood Ratio & 2,732 & 4 & ,604 \\
\hline $\begin{array}{l}\text { Linear-by-Linear } \\
\text { Association }\end{array}$ & ,025 & 1 & ,875 \\
\hline $\mathrm{N}$ of Valid Cases & 262 & & \\
\hline
\end{tabular}

Chi Square test has been applied to check the hypothesis, and the results are shown in Table 23. It can be concluded from the table that the Assymp. Sig value is 0.607 . Since this value is $p>0.05$, the answers regarding the present value of money do not differ in terms of age groups. For this reason, H9 has been rejected.

$\mathrm{H}_{10}$ : Answers regarding calculation of mortgage interest differ as to income level groups.

The results of the KI Square test used to confirm whether the answers asked for calculating the mortgage interest have changed or have not changed the income level groups are given in Table 24. As demonstrated in the table, the Assymp. Sig value is 0.139 . Considering that this value is $p$ $>0.05, \mathrm{H}_{10}$ has been rejected.

Table 24. Chi Square Test Results

\begin{tabular}{|c|c|c|c|}
\hline \multicolumn{4}{|c|}{ Chi-Square Tests } \\
\hline & Value & Df & $\begin{array}{c}\text { Asymptotic } \\
\text { Significance } \\
\text { (2-sided) }\end{array}$ \\
\hline Pearson Chi-Square & $6,934^{\mathrm{a}}$ & 4 &, 139 \\
\hline Likelihood Ratio & 6,545 & 4 &, 162 \\
\hline $\begin{array}{c}\text { Linear-by-Linear } \\
\text { Association }\end{array}$ & 4,344 & 1 &, 037 \\
\hline N of Valid Cases & 266 & & \\
\hline
\end{tabular}

a. 0 cells $(0,0 \%)$ have expected count less than 5 . The minimum expected count is 8,48 . 
$\mathrm{H}_{11}$ : There is a notable link between retirement responses and income level groups.

In order to test the $\mathrm{H} 11$ hypothesis, Chi-Square test has been conducted. In accordance with the results of the test, Asymp. Sig value is 0.20 . On the account of the fact that this value is less than 0.05 , there is a significant correlation between retirement responses and income level groups. $\mathrm{H}_{11}$ has been accepted.

Table 25. Chi-Square Test Results

\begin{tabular}{|c|c|c|c|}
\hline \multicolumn{4}{|c|}{ Chi-Square Tests } \\
\hline & Value & Df & $\begin{array}{l}\text { Asymptotic } \\
\text { Significance } \\
\text { (2-sided) }\end{array}$ \\
\hline Pearson Chi-Square & $11,717^{\mathrm{a}}$ & 4 & 020 \\
\hline Likelihood Ratio & 10,407 & 4 & 034 \\
\hline $\begin{array}{l}\text { Linear-by-Linear } \\
\text { Association }\end{array}$ & 4,463 & 1 & ,035 \\
\hline $\mathrm{N}$ of Valid Cases & 268 & & \\
\hline $\begin{array}{l}\text { a. } 0 \text { cells }(0,0 \%) \text { have } \\
\text { expected count is } 7,51 \text {. }\end{array}$ & ed $c$ & & The minimur \\
\hline
\end{tabular}

$\mathrm{H}_{12}$ : There is a marked correlation between credit rates and inflation related answers and income level groups.

Chi Square test has been designated to test the hypothesis, and the results are given in Table 26. When we look at the table, we can detect that the Assymp. Sig value is 0.001 . Since this value is $p<0.05$, there is a meaningful relationship between credit rates and inflation related answers and income level groups. For this reason, $\mathrm{H}_{12}$ has been accepted.

Table 26. Chi-Square Test Results

\begin{tabular}{|c|c|c|c|}
\hline \multicolumn{4}{|c|}{ Chi-Square Tests } \\
\hline & Value & $\mathrm{df}$ & $\begin{array}{c}\text { Asymptotic } \\
\text { Significance } \\
\text { (2-sided) }\end{array}$ \\
\hline Pearson Chi-Square & $18,309^{\mathrm{a}}$ & 4 &, 001 \\
\hline Likelihood Ratio & 18,734 & 4 &, 001 \\
\hline $\begin{array}{c}\text { Linear-by-Linear } \\
\text { Association }\end{array}$ & 11,546 & 1 &, 001 \\
\hline N of Valid Cases & 260 & & \\
\hline O cell $(0,0 \%)$ hex &
\end{tabular}

a. 0 cells $(0,0 \%)$ have expected count less than 5 . The minimum expected count is 18,50 .

\section{Conclusions}

A survey consisting of 6 tests and demographic questions aimed at determining the level of financial literacy has been conducted among 280 people who are aged 17-60 and live in Baku. The data obtained have been evaluated with SPSS 24, Frequency and Crosstab analyzes from descriptive analyzes, and Hypotheses have been tested with Chi-Square. A total of 12 Hypotheses have been developed. $\mathrm{H}_{1}, \mathrm{H}_{3}, \mathrm{H}_{4}, \mathrm{H}_{5}, \mathrm{H}_{6}, \mathrm{H}_{8}, \mathrm{H}_{11}, \mathrm{H}_{12}$ have been accepted, $\mathrm{H}_{2}, \mathrm{H}_{7}, \mathrm{H}_{9}, \mathrm{H}_{10}$ have been rejected. When we look at the results of the analysis, we can state that although the number of men who have responded correctly to the tests is higher than women, in terms of income level and age group, the results for some tests differ especially in regard to retirement, loan rates and inflation. When it is generally evaluated, the questions about "Present value of money" and "Relationship between credit rates and inflation" have higher number of the wrong answers than the correct ones. For the other 4 questions, the number of respondents who have answered correctly is more than those who have answered incorrectly. In fact, the difference between those who have responded inaccurately and those who have responded accurately for aforementioned 4 questions is higher.

\section{REFERENCES}

[1] Kucukaslan, A. Financial Literacy: A Research on Public Accountants and Financial Advisors in Kayseri Province. Gümüşhane University, Institute of Social Sciences, Department of Business Administration, Master Thesis.

[2] Aksoylu, S., Boztosun, D., ALTINIŞIK, F., \& Baraz, E. H. A Baseline Investigation of Financial Literacy Levels: The Case of Kayseri Province. Journal of Accounting \& Finance, (75) pp.229-246. 2017.

[3] Liaqat, F., Mahmood, K., \& Ali, F. H. Demographic and socio-economic differences in financial information literacy among university students. Information Development, 2020. DOI: $10.1177 / 0266666920939601$

[4] Bayar, Y., Sezgin, H. F., Ozturk, O. F., \& Shashmaz, M. U. Financial Literacy and Financial Risk Tolerance of Individual Investors: Multinomial Logistic Regression Approach. SAGE Open, 10(3), 2020. DOI: $10.1177 / 2158244020945717$

[5] Razak, D. A., Hamdan, H., \& Uddin, M. N. (2020). The Effect Of The Demographic Factors Of Micro-Entrepreneur On Financial Literacy: Case Of Amanah Ikthıar Malaysıa (AIM).

[6] Barmaki, N. A Research to Determine the Financial Literacy Levels of University Students: The Case of Hacettepe University. Hacettepe University Institute of Social Sciences Family and Consumer Sciences. Doctoral Thesis. 2015.

[7] Temizel, F. \& Bayram, F. Financial Literacy: A Research for Anadolu University Faculty of Economics and Administrative Sciences (İ̈BF) Students. Cumhuriyet University Journal of Economic and Administrative Sciences, 12 (1), pp.73-86. 2011.

[8] Hogart, J., Beverly, S. \& Hilgert, M. Patterns Of Financial Behaviors: Implications For Community Educators And Policy Makers. Discussion, 2003. https://www.federalreserve.gov/communityaffairs/national/ CA_Conf_SusCommDev/pdf/ hogarthjeanne.pdf, 01.07.2018.

[9] K1lıch, Y., Ata A. H. \& Seyrek, H. I. Financial Literacy: A Study for University Students. Accounting and Finance 
Magazine, 66, pp.129-150. 2015.

[10] Worthington, A. C. Predicting Financial Literacy İn Australia. Financial Services Review, 15, pp.59-79. 2006.

[11] Dvorak, T. \& Hanley, H. Financial Literacy And The Design Of Retirement Plans. The Journal of Socio-Economics, 39, pp.645-652. 2010. DOI: 10.1016/j.socec.2010.06.013.

[12]Barısh, S. Financial Literacy and Budgeting Behavior: A Study on University Students. TESAM Academy Dergisi Turkish Journal of TESAM Academy, 3 (2). pp.13-38, 2462. 2016.

[13] Ozdemir, A., Temizel, F., Sonmez, H. \& Er, F. Financial Literacy of University Students: A Case Study For Anadolu University, Turkey. International Journal of Management Economics and Business, 11(24): pp.97- 110. 2015.

[14] Bicher, E. B. Evaluation of University Students' Attitudes and Behaviors Related to Financial Literacy. Atatürk University Institute of Social Sciences Journal, 20 (4): pp.1501-1517. 2016.

[15] Shamiloğlu, F., Kahraman, Y. E. \& Bağcı, H. Financial Literacy Research: An Application on Erciyes University Students. International Journal of Management Economics and Business, Icafr 16 Special Issue, pp.308-318. 2016.

[16] Shantash, F. \& Demirgil, B. A Research on the Determination of Economic Literacy Level. Journal of Academic Perspective, 48, pp.46-60. 2015. DOI: 10.22139/jobs.286671

[17] Ergun, B., Shahin, A. \& Ergin, E. Financial Literacy: A Study on Business Administration Students, International Journal of Social Studies, 7 (34), pp.847- 864. 2014.

[18] Sarigul, H. A Survey of Financial Literacy Among University Students. Accounting and Finance Magazine, 64, pp.207-224. 2014.

[19] Bayram, S. Financial Literacy and Money Management Behaviors: An Application on Anadolu University Students. Master Thesis, Anadolu University, Eskishehir. 2010.

[20]Danes, S. M. and Hira, T. K. Money Management Knowledge of College Students. Journal of Student Financial Aid, 17(1): pp.3-16. 1987.

[21] Volpe, R. P., Chen, H. and Pavlicko, J. J. Personal Investment Literacy Among College Students: A Survey. Financial Practice and Education, 6(2), pp.86-94. 1996.

[22] Chen, H. \& Volpe, R. P. An Analysis of Personal Financial Literacy Among College Students. Financial Services Review, 7(2), pp.107-128. 1998.

[23] Kieschnick, D. A. Financial Knowledge Levels and Savings Behaviors of Bermudian High School Seniors at Cedar Bridge Academy. Master of Science, Ames: Iowa State. 2006. DOI: $10.31274 / \mathrm{rtd}-180813-9896$

[24] Jorgensen, B. L. Financial Literacy of College Students: Parental and Peer Influences. Master of Science. Virginia Polytechnic Institute and State University. Blacksburg, Virginia. 2007.

[25] Mandell, L. \& Klein, L. S. The Impact of Financial Literacy Education on Subsequent Financial Behavior. Journal of Financial Counseling and Planning, 20(1): pp.15-24. 2009.
[26] Robb, C. A. \& Sharpe, D.L. (2009). Effect of Personal Financial Knowledge on College Students'Credit Card Behavior. Journal of Financial Counseling and Planning, 20(1), pp. 25- 40. 2009.

[27] Cameron, M. P. Calderwood, R. Cox, A. Lim, S. \& Yamaoka, M. Factors Associated with Financial Literacy among High School, Department. Hamilton, New Zealand: Department of Economics, University of Waikato. Volume 16, Part A, pp.12-21. 2014. DOI: 10.1016/j.iree.2014.07.006.

[28] Yardımcioglu, M. \& Yoruk, A. Analysis Of Financial Literacy And Financial Awareness in Turkey. Journal of Accounting and Tax Applications, 9 (2), 173-208. 2016.

[29] Yildırım, M., Bayram, F., Oguz, A., \& Gunay, G. (2017). Financial literacy level of individuals and its relationships to Demographic variables. Mediterranean Journal of Social Sciences, 8(3), 19. 2017. DOI: 10.5901/mjss.2017.v8n3p19.

[30] Baker, H. K., Kumar, S., Goyal, N., \& Gaur, V. (2019). How financial literacy and demographic variables relate to behavioral biases. Managerial Finance.pp.1-24. 2019. DOI:10.1108/MF-01-2018-0003

[31] Setyowati, A., Harmadi, H., \& Sunarjanto, S. Islamic financial literacy and personal financial planning: A socio-demographic study. Jurnal Keuangan dan Perbankan, 22(1): pp.1-13. 2018. DOI: 10.26905/jkdp.v22i1.1625

[32] Shusha, A. A. Does financial literacy moderate the relationship among demographic characteristics and financial risk tolerance? Evidence from Egypt. Australasian Accounting, Business and Finance Journal, 11(3), pp.67-86. 2017. DOI:10.14453/aabfj.v11i3.6

[33] Janor, H., Yakob, R., Hashim, N.A., Zanariah, Z., \& Wel, C.A.C. Financial literacy and investment decisions in Malaysia and United Kingdom: A comparative analysis. Geografia-Malaysian Journal of Society and Space, 12(2). 2016.

[34] Dewanty, N., \& Isbanah, Y. Determinants of the Financial Literacy: A Case Study on Career Woman in Indonesia. Etikonomi Jurnal Ekonomi, 17(2), pp.285-296. 2018. DOI: 10.15408/etk.v17i2.6681

[35] Garg, N., \& Singh, S. Financial literacy among youth. International journaL of sociaL economics. 2018. DOI:10.1108/IJSE-11-2016-0303

[36] Kimiyaghalam, F., \& Yap, S. Level of financial literacy in Malaysia. International Journal of Research, 4(7), pp.1065-1074. 2017.

[37] Nanziri, E. L., \& Leibbrandt, M. Measuring and profiling financial literacy in South Africa. South African Journal of Economic and Management Sciences, 21(1), pp.1-17.2018. DOI: 10.4102/sajems.v21i1.1645.

[38] Widityani, S. F., Faturohman, T., Rahadi, R. A., \& Yulianti, Y. Do Socio-Demographic Characteristics And Islamic Financial Literacy Matter For Selecting Islamic Financial Products Among College Students In Indonesia?. Journal of Islamic Monetary Economics and Finance, 6(1).2020. DOI: 10.21098/jimf.v6i1.1057.

[39] Asbi, A., Ramiah, V., Yu, X., Wallace, D., Moosa, N., \& Reddy, K. (2020). The determinants of recovery from the Black Saturday bushfire: demographic factors, behavioural 
characteristics and financial literacy. Accounting \& Finance, 60(1), pp.15-46. 2020. DOI: 10.1111/acfi.12575

[40] Oztop, A. O., \& Kuyu, E. Influence Of Soc10-Demographic Characteristics, Financial Literacy And Mood On Financial Risk Tolerance. Journal of Business Economics and Finance, 9(3), 209-222. 2020.2 DOI: 10.17261/Pressacademia.2020.1297.

[41] Marime, N., Magweva, R., \& Dzapasi, F. D. Demographic determinants of financial literacy in the Masvingo Province of Zimbabwe1.pp.1-18. 2020.

[42] Lusardi, A. Financial Literacy: An Essential Tool for Informed Consumer Choice? NBER Working Paper No.14084.National Bureau of Economic Research, Inc. 2008. DOI: $10.3386 /$ w14084.

[43] Lusardi, A., Mitchell, O. S. \& Curto, V. (2011). Financial
Literacy Around The World: An Overview. Journal of Pension Economics and Finance, 10, pp. 497-508. 2011. DOI: 10.3386/w17107

[44] Singh, Chetan, and Raj Kumar. "Financial literacy among women: Indian Scenario." Universal Journal of Accounting and Finance, Vol 5(2). pp.46-53. 2017. DOI: 10.13189/ujaf.2017.050202.

[45] Schagen, S., \& Lines, A. (1996). Financial literacy in adult life: a report to the Natwest Group Charitable Trust (pp. 36-45). NFER.

[46] Islamlı, I., \& Aliyev, Y. (2016). Finansal Okur Yazarlılığın Sosyo-Ekonomik Duruma Etkisi: Bakü Örneği. Assam Uluslararası Hakemli Dergi, 3(6), 11-20.

[47] Ahmadov, Fariz, Turan Ahmedov, and Yusif Aliyev. "MaliyyəSavadlılığı: Konseptual vəTarıxı Inkışaf."Turan: Stratejik Arastirmalar Merkezi9.34 (2017): 278 